\title{
Discussions on the Construction of Indexical System for Evaluation of Enterprise's Marketing Capability
}

\author{
Shang Qingyun \\ Jilin Institute of Chemical Industry \\ Jilin City,Jilin Province,China \\ E-mail: 13514329510@163.com
}

\begin{abstract}
The enterprise's marketing ability is critical for the survival of enterprises in the complex competition environment. At present, the theory focuses on the qualitative analysis of marketing ability, based on the logical framework of marketing ability, this paper constructs the evaluation index system of the marketing ability, in order to make quantitative analysis on the marketing ability. Because this system is comprehensive, systematical, and easy to operate, the evaluation index system is practical and significant for improving the evaluation level of marketing ability of all industries.
\end{abstract}

Keywords-Marketing ability, Evaluation index system, Quantitative analysis

\section{INTRODUCTION}

The marketing ability is the management ability of enterprise in the process of transferring products and services from producers to consumers or users.

At present, the theory focuses on the qualitative analysis of marketing ability, but little about quantitative analysis. Quantitative analys is is of great practical significance in the evaluation of enterprise's marketing ability, it makes the evaluation of marketing capability extend from enterprise to enterprise, and then makes the comparison between the marketing ability of enterprises more objective, simple, and easy to operate.

This paper is based on the logical framework of marketing ability, building a comprehensive, workable evaluation index system of marketing ability, and make statistical tests about the rationality, reliability and relevance of the enterprise's marketing ability index.

\section{THE LOGICAL FRAMEWORK OF MARKETING ABILITY FORMATION}

\section{A. Assumptions}

The normal development of enterprise's marketing ability relies on the perfection and smooth running of the marketing information system. Marketing information system of enterprise collects all kinds of market information, including competitors, consumers' demand, policies and regulations, which provides a scientific bas is for decisionmaking, and makes definite objects for enterprise marketing activities, so as to avoid waste of resources in blind marketing, and ensure the normal development of marketing ability.

The marketing strategy provides the basic direction of marketing activities, so that the marketing ability can be focused, and then give full play to the marketing ability. Marketing strategy is the concrete embodiment of the enterprise's marketing ability, which is decisive to the marketing ability. Marketing strategy is the means to realize the goal of marketing, it is a link that transfers products from producers to consumers. It essentially reflects the marketing capacity that whether the means are brilliant, or if the enterprise can transfer the products smoothly. Therefore, so to speak, choosing the appropriate marketing strategy determines the enterprise's marketing ability.

Marketing implementation ensures that marketing capabilities can be put into practice, and the smooth development of marketing ability. Marketing imple mentation guarantee ensures the process of marketing activities, in which the marketing ability is embodied. So we can say that marketing implementation plays a decisive role in marketing ability.

Marketing efficiency reflects the implementation effect and the interests of marketing ability, meanwhile quantifies the marketing ability, and make it more specific, and more intuitive.

The evaluation indexes of enterprise's marketing ability are not compatible with each other, and there is no correlation between them.

\section{B. Logical Framework}

Based on the assumption, we know that the marketing ability is affected by the marketing information system, marketing strategy, marketing implementation guarantee, and marketing interests, which leads to following hypothes is model, as shown in figure 1. Logical framework can be interpreted as:

Enterprise's marketing ability is influenced by following factors: the perfection and smooth running of the marketing information system, the appropriate marketing strategy, the combination of marketing strategies, the real execution of marketing implementation guarantee, and marketing efficiency; but these factors are not related to each other.

The operation process of the marketing information system consists of information collection, information analysis, information using, the original information collected by the marketing information system is frag mented, it must be input into the information analys is system to be 
analyzed and evaluated. The information will has value after being analyzed and evaluated, and it can be promptly transferred to the marketing manager for decision-making; The strategic goals of the enterprise determine the direction of marketing activities, and under the guidance of the goals, enterprises subdivides the market, choosing target market, positioning target market in an unique way, and determining the products' importance in customers' heart. Finally, in a written form, the above content will be concreted into a workable marketing strategic planning; Marketing strategy consists of product strategy, pricing strategy, distribution strategy, and promotion strategy, all these strategies are irrelevant; marketing implementation needs the support of manpower, material and financial resources, these three resources also are not related to each other; market efficiency reflects the enterprise's marketing ability from the ability of exploiting market, sales effectiveness reflects the enterprise's marketing efficiency from the profitability, and sales growth.

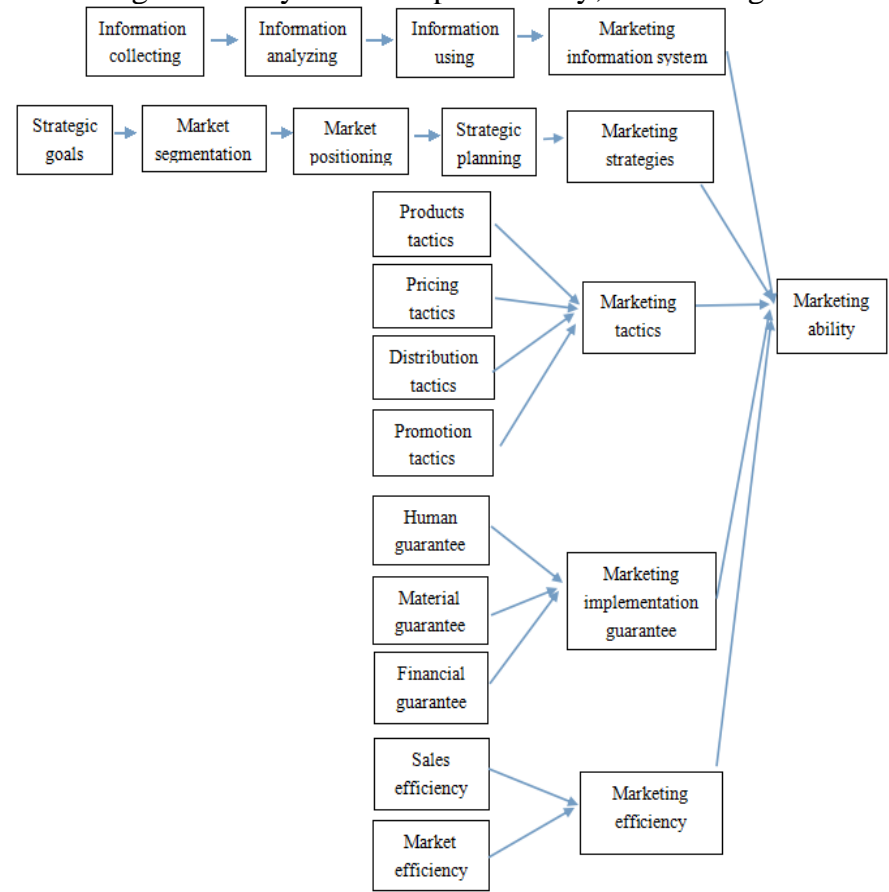

Figure 1. The Logical Framework Formed by Marketing Ability

\section{EVALUATION INDEX SYSTEM OF MARKETING ABILITY}

According to the logical framework above, we can transform and extend to a more systematic, comprehensive, and workable evaluation index system of marketing capability. The evaluation index system of enterprise's marketing ability consists of 1 first level index, 5 second level indexes, and 17 third level indexes, as shown in table 1.

Quantification of the assessment index: The marketing capacity evaluation is a quantitative analysis, which uses numbers to reflect the enterprise's marketing ability, therefore the evaluation index needs to be quantified. In the process of testing the evaluation index, the study is based on the scholars and the enterprise marketing executives' opinion and judgment about the reliability, rationality and relevance of the evaluation index, so we use attitude measurement techniques to quantify the evaluation index. In the scale, there are two reasons why we use numbers represents the marketing ability level: First, it is easy for statistical analysis; secondly, numbers make marketing ability evaluation itself become easy, clear and definite. The Likert scale is easy to design and process, and it can be easily understood, so it is applicable in postal questionnaire, telephone interview and personnel interviews. This study uses 5 level ordinal scale of Likert scale. The effect of marketing ability evaluation index on marketing ability is divided into: great, big, general, small, very small, and the corres ponding numbers are 5, 4, 3, 2, 1 .

TABLE I. EVALUATION INDEX SYSTEM OF MARKETING ABILITY

\begin{tabular}{|c|c|c|c|}
\hline $\begin{array}{l}\text { First Level } \\
\text { Index }\end{array}$ & $\begin{array}{c}\text { Second } \\
\text { Level Index }\end{array}$ & $\begin{array}{l}\text { Third Level } \\
\text { Index }\end{array}$ & Instruction \\
\hline \multirow{7}{*}{$\begin{array}{c}\text { Marketing } \\
\text { Ability }\end{array}$} & \multirow{3}{*}{$\begin{array}{c}\text { Marketing } \\
\text { Information } \\
\text { System }\end{array}$} & $\begin{array}{c}\text { Information } \\
\text { collecting system }\end{array}$ & $\begin{array}{l}\text { The required in formation } \\
\text { relies on the internal } \\
\text { reporting system, } \\
\text { marketing information } \\
\text { system, marketing } \\
\text { research system. }\end{array}$ \\
\hline & & $\begin{array}{l}\text { Information } \\
\text { analyzing } \\
\text { system }\end{array}$ & $\begin{array}{l}\text { Enterprises have their } \\
\text { own data center, } \\
\text { information input and } \\
\text { output mechanism, as } \\
\text { well as professional } \\
\text { computer management } \\
\text { personnel. }\end{array}$ \\
\hline & & $\begin{array}{l}\text { Information } \\
\text { reporting } \\
\text { system }\end{array}$ & $\begin{array}{l}\text { Enterprises have a } \\
\text { periodic, and non } \\
\text { periodic system to report } \\
\text { market research. }\end{array}$ \\
\hline & \multirow{4}{*}{$\begin{array}{l}\text { Marketing } \\
\text { Strategies }\end{array}$} & Market goals & $\begin{array}{l}\text { Marketing objectives } \\
\text { must be consistent with } \\
\text { the overall business } \\
\text { objectives, including } \\
\text { specific and clear } \\
\text { corporate objectives }\end{array}$ \\
\hline & & $\begin{array}{c}\text { Market } \\
\text { segmentation }\end{array}$ & $\begin{array}{l}\text { Market segmentation } \\
\text { should be based on } \\
\text { certain segmentation } \\
\text { criteria, and has } \\
\text { difference, measurability, } \\
\text { sufficient interest, } \\
\text { accessibility, and } \\
\text { feasibility. }\end{array}$ \\
\hline & & $\begin{array}{c}\text { Market } \\
\text { positioning }\end{array}$ & $\begin{array}{l}\text { Enterprises should have } \\
\text { clear, objective, stable } \\
\text { and unique product, } \\
\text { brand and corporate } \\
\text { positioning. }\end{array}$ \\
\hline & & $\begin{array}{l}\text { Strategic } \\
\text { planning }\end{array}$ & $\begin{array}{lrr}\text { The total } & \begin{array}{r}\text { cost } \\
\text { of } \\
\text { enterprise should }\end{array} \text { be } \\
\text { specific, and } & \text { has } \\
\text { differences } & & \text { and } \\
\text { concentrated } & \text { strat egies } \\
\text { and tactics. } & & \end{array}$ \\
\hline
\end{tabular}




\begin{tabular}{|c|c|c|}
\hline \multirow[t]{4}{*}{$\begin{array}{c}\text { Marketing } \\
\text { Tactics }\end{array}$} & Products tactics & $\begin{array}{l}\text { Enterprises should have } \\
\text { new products research } \\
\text { and development team to } \\
\text { cater to market needs: } \\
\text { should design the best } \\
\text { product portfolio, and } \\
\text { choose marketing } \\
\text { strategies for different } \\
\text { products' life cycle: } \\
\text { should include perfect } \\
\text { pre-sale, sale and after } \\
\text { sale service }\end{array}$ \\
\hline & $\begin{array}{l}\text { Pricing } \\
\text { tactics }\end{array}$ & $\begin{array}{l}\text { Enterprise's pricing } \\
\text { should consider the costs } \\
\text { and be competitive: } \\
\text { should take certain } \\
\text { pricing strategy to } \\
\text { promote sales. }\end{array}$ \\
\hline & $\begin{array}{l}\text { Distribution } \\
\text { tactics }\end{array}$ & $\begin{array}{l}\text { Enterprises should } \\
\text { choose the best mode of } \\
\text { distribution channels } \\
\text { according to factors of } \\
\text { market and products, the } \\
\text { conditions of enterprises, } \\
\text { competitors: should } \\
\text { establish the perfect } \\
\text { middlemen management } \\
\text { mechanism. }\end{array}$ \\
\hline & $\begin{array}{l}\text { Promotion } \\
\text { tactics }\end{array}$ & $\begin{array}{l}\text { The enterprise choose } \\
\text { proper marketing } \\
\text { portfolio that based on } \\
\text { advertising, } \\
\text { promotion,public sales } \\
\text { relations, marketing } \\
\text { personnel according to } \\
\text { the target, product, } \\
\text { enterprise. }\end{array}$ \\
\hline \multirow{3}{*}{$\begin{array}{c}\text { Marketing } \\
\text { Implementat } \\
\text { ion } \\
\text { Guarantee }\end{array}$} & $\begin{array}{c}\text { The enterprise's } \\
\text { marketing } \\
\text { organization }\end{array}$ & 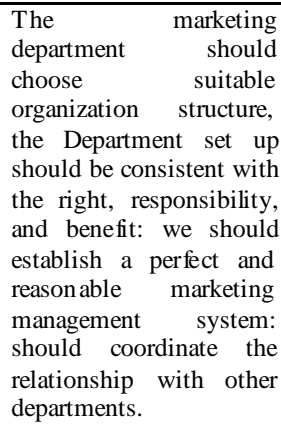 \\
\hline & $\begin{array}{c}\text { Marketing } \\
\text { human resources }\end{array}$ & $\begin{array}{l}\text { Enterprises should } \\
\text { establish the marketing } \\
\text { team recruitment, } \\
\text { training, assessment, } \\
\text { rewards and punishment, } \\
\text { such as: marketing team } \\
\text { should have periodic and } \\
\text { non periodic training and } \\
\text { other learning } \\
\text { opportunities. }\end{array}$ \\
\hline & $\begin{array}{c}\text { Financial } \\
\text { management } \\
\text { mechanism }\end{array}$ & $\begin{array}{l}\text { The enterprise shall have } \\
\text { the annual marketing } \\
\text { budget and settlement: } \\
\text { reasonable marketing } \\
\text { funds scheduling and } \\
\text { operation can be met } \\
\text { timely:payment should } \\
\text { be timely recovered in } \\
\text { order to reduce bad } \\
\text { debts. }\end{array}$ \\
\hline
\end{tabular}

\begin{tabular}{|l|l|l|l|}
\hline \multirow{2}{*}{} & \multirow{2}{*}{$\begin{array}{l}\text { Marketing } \\
\text { Efficiency }\end{array}$} & Sales profit rate & $\begin{array}{l}\text { Profit rate=The sales } \\
\text { profit/Total amount of } \\
\text { sals } \times 100 \%\end{array}$ \\
\cline { 3 - 4 } & Sales growth rate & $\begin{array}{l}\text { Profit rate=This period } \\
\text { sales-last period sales } \\
\text { /Last period sales } \times 100 \%\end{array}$ \\
\cline { 2 - 3 } & $\begin{array}{l}\text { The expansion } \\
\text { rate of market }\end{array}$ & $\begin{array}{l}\text { Profit rate=This period's } \\
\text { market share - last } \\
\text { period's market } \\
\text { share/This period's } \\
\text { market share } \times 100 \%\end{array}$ \\
\hline
\end{tabular}

The evaluation index system of marketing ability is based on the logical framework, which proves that it is logical. But wether the indexes are rational, reliable, or relevant, they need to be further proved by the statistical test.

This research will design the questionnaire of marketing ability evaluation index, and then distribute them to the marketing experts and marketing directors. Then we use their opinions and judgment to test the reliability, rationality and relevance of the marketing ability indexes.

\section{A. Design of the Questionnaire of Marketing Ability Evaluation}

According to the second level and third level indicators of the index system, we directly come to the questions on questionnaire, and then design and test the questionnaire. The final questionnaire consists of 5 level sequential scale of 22 .

\section{B. The Collection of Data}

We conducted a questionnaire survey on the marketing students in Jilin Institute of Chemical Technology and enterprise marketing directors. A total of 150 questionnaires were recovered, of which 120 were valid questionnaires, and the effective recovery rate of the questionnaire was $80 \%$.

\section{Statistical test}

Analysis of Reliability : As for this research, reliability refers to wether the questions in questionnaire can reliably reflect the enterprise's marketing ability. There are lots of methods to estimate reliability, and different results reflect different aspects of reliability. We adopt the most commonly used kronor Baja alpha reliability coefficient method to test the reliability of questionnaire.

We use the SPSS11.0 statistical software to process the collected data for reliability analysis, and the result is a $=0.7714$, generally speaking, more than $70 \%$ of the questionnaire are highly reliable. It can be said, the above 5 second level indexes are important factors that affects the first level index. 
TABLE II. COMMUNALITIES OF THE SECOND LEVEL INDEXES

\begin{tabular}{|c|c|c|}
\hline & Initial & Extraction \\
\hline $\mathrm{A}$ & 1.000 & .771 \\
\hline $\mathrm{B}$ & 1.000 & .813 \\
\hline $\mathrm{C}$ & 1.000 & .863 \\
\hline $\mathrm{D}$ & 1.000 & .779 \\
\hline $\mathrm{E}$ & 1.000 & .511 \\
\hline
\end{tabular}

Extraction Method: Principal Component Analysis

TABLE III. CORRELATIONS OF THE SECOND LEVEL INDEXES

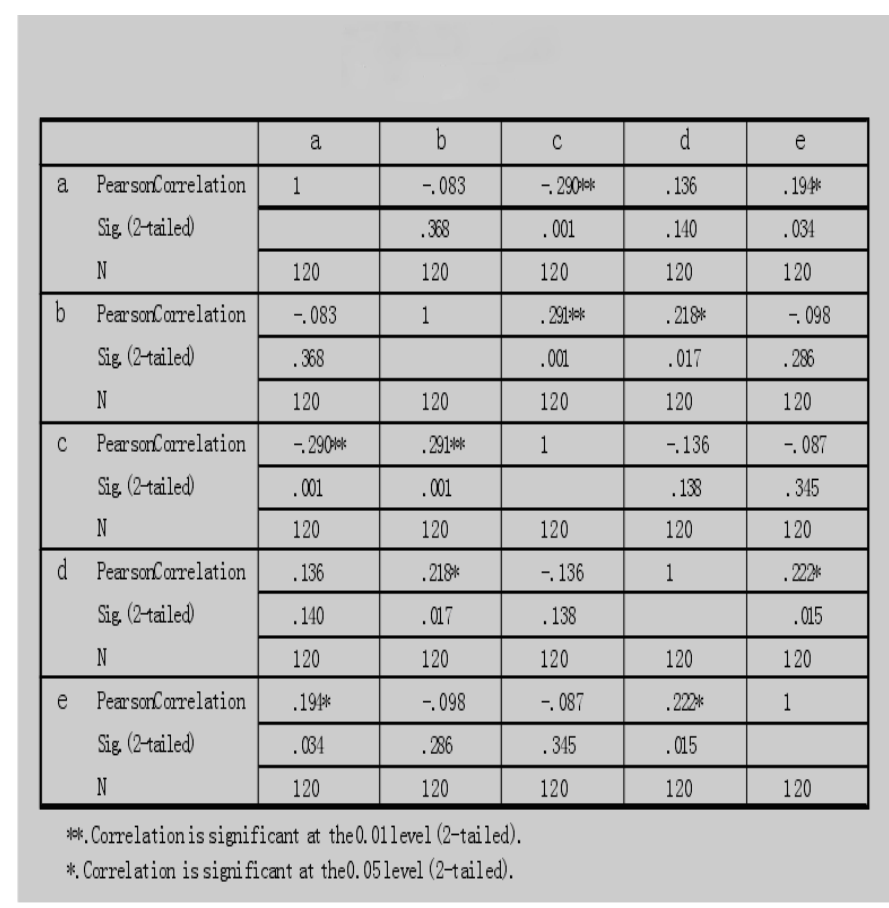

Analysis of Rationality: We use the SPSS11.0 statistical software for factor analysis. According to the common degree of evaluation index, we test each indicator's influence on marketing ability. The bigger the joint degree is, the more the index depends on common factor, that is, these common factors can more effectively explain the evaluation index. Generally speaking, when the joint degree is higher than 0.4 , the common factor can exp lain the evaluation index properly, and relatively small numbers can be eliminated based on experience. The analysis results are in table 2 .

The factor analysis results show, common degree of each evaluation index factor in questionnaire is higher than 0.511, which means that the evaluation index in the questionnaire impacts marketing ability greatly. It's unnecessary to remove any index.
Analysis of Correlation: In order to study the relationship between these 5 indexes, we conducted a correlation analysis of the 5 first level indicators, as shown in table 3.

The above results show, there are positive correlation and negative correlation among these 5 second level indexes, but in general, they are less than 0.3. In general, if the correlation is greater than 0.8 , it is believed that there is strong linear correlation between two variables, if less than 0.3 , there is weak linear correlation between two variables. Therefore, we will ignore the weak correlation, and present the assumptions that these 5 evaluation indexes are independent of each other, and the hypothesis that there is no correlation is true.

By statistic analysis, we come to a conclusion: the logical framework of index system is basically valid, the indexes of the systemare applicable and reasonable.

\section{DETERMINATIONOF THE INDEX WEIGHT}

Research achievements of Shanghai Institute of Quality Management and Science show: starting from the actual survey data to determine the weights, extracting the relevant information from the data itself, which can fully reflect the wishes of customers. Its strong objectivity will not be easily affected by other subjective factors. The effective methods to determine weight are average assignment method, principal component analysis, and factor analysis. The study found that results of average assignment method are the most highly related to marketing ability, followed by the method of factor analysis, and main component method turns out the lowest correlation. But there are not greatly different standard deviations of these three methods.

The objectivity of the factor analysis method is relatively strong, so we use factor analysis to determine the weight of each second level index in evaluating enterprises ' marketing ability. According to the data of factor analysis, we can use the method of communalities percentage to determine the weight of the second level indexes. As shown in table 4.

TABLE IV. Weight ofthe SECOND LEVEL EVALuATION INDEXES

\begin{tabular}{|c|c|c|c|}
\hline Variables & Initial & Extraction & Weight \\
\hline $\mathrm{A}$ & 1.000 & .771 & 0.20 \\
\hline $\mathrm{B}$ & 1.000 & .813 & 0.22 \\
\hline $\mathrm{C}$ & 1.000 & .863 & 0.23 \\
\hline $\mathrm{D}$ & 1.000 & .779 & 0.21 \\
\hline $\mathrm{E}$ & 1.000 & .511 & 0.14 \\
\hline
\end{tabular}

After determining the weight of the second level indexes, the marketing experts and scholars mark the indexes, finally the two results are weighted averagely, then we can get the first class index evaluation of enterprise's marketing ability.

At present, the marketing ability has not been defined as unified in theory, and the analysis of marketing ability is mainly qualitative. Based on the logical framework formed by marketing ability, this paper builds a comprehensive, workable evaluation index system of marketing ability, 
including 1 first level indicators, 5 second level indicators and 17 third level indicators.

This study uses the Likert scale to quantify evaluation indexes, and makes statistical test on the questionnaire information, which proves the reliability, rationality and correlation of the selected indexes.

\section{REFERENCES}

[1] Philip Kotler.Marketing Management: Application, Planning, Implementation and Control[M].Shanghai People's Publishing House, 1997.

[2] Wu Jianping, Tian Jian, Yao Huili, Wu Dinglong. Marketing Guide[M].Science Press, 2004.

[3] Wang Fanghua, Gu Feng. Marketing[M]. Shanghai People's Publishing House, 2003.

[4] [Dr.]John Brown, Guo Cheng translated. Marketing Management [M]. Zhengzhou University Press, 2004.

[5] Feng Zhenhuan, Luo Yongtai. Study on the evaluation index system and method of implicit marketing performance[J].The Productivity Research, 2004(3).

[6] Chen Zhongwei. Construction of enterprise's market ing ability index system [J]. Zhejiang Statistics, 1998 (4).

[7] Michael Potter. Competitive Strategy[M]. Chinese Financial and Economic Publishing House, 1989.

[8] Chen Zhongwei. Construction of enterprise's marketing ability index system [J]. Zhejiang Statistics, 1998 (4) 